\title{
Anatomy of the Privatization of State-Owned Enterprises (SOEs) in Ghana: Implication for Policy and Accountability
}

\author{
Eugene Danso \\ Department of Political Science, Brock University \\ 500 Glenridge Avenue, St. Catharines, L2S 3A1, Ontario, Canada \\ E-mail: ed17pa@brocku.ca
}

Received: Oct. 9, 2019 Accepted: Nov. 13, 2019 Online published: Nov. 22, 2019

doi:10.5296/jpag.v9i4.15600～URL: https://doi.org/10.5296/jpag.v9i4.15600

\begin{abstract}
With the administrative and operational functions of State-Owned Enterprises (SOEs) becoming increasingly complex and sophisticated among developing countries by the 1980s, privatization was recommended by the IMF/World Bank as a remedy to these institutional deficiencies. This is contingent on the neoclassical debate that private ownership rather than public ownership of management and operations of SOEs results in prudent policy process and accountability. Therefore, this study sought to assess the validity of this assertion by employing the Principal-Agent theory in assessing the level of accountability between the citizens (principal) and the government (agent) during private ownership of service delivery. As a qualitative study, this paper adopts unobtrusive content analysis of an empirical study of the privatization of Ghana Water Company Limited (GWCL). The government (agent) under the Principal-Agent theory is to ensure that the private operator, Aqua Vitens Rand Limited (AVRL) respects the terms of divestiture, while upholding the principles of accountability. However, the findings of the study suggest that the failure of government (agent) to uphold core accountability mechanisms such as transparency, accessibility to information, sense of ownership, responsiveness, and conformity to established monitoring and evaluation measures, contributed to the inability to achieve key performance targets, leading to the unsuccessful policy outcome of the privatization contract. This paper, therefore, argues that the failure to adopt accountability mechanisms in the divestiture of SOEs will inevitably compromise administrative policy outcomes.
\end{abstract}

Keywords: accountability, privatization, principal-agent theory, state-owned enterprises 


\section{Introduction}

In the early 1980s, the drivers of change, particularly financial pressures, pushed most countries towards a focus on making the public sector more competitive and public administrators more efficient by offering value for money, flexibility of choice, greater transparency and accountability (Kalimullah et al., 2012; Robinson, 2015). Also, the push towards privatization was contingent on the neoclassical hypothesis that private ownership of business, as compared to public ownership, results in more efficient and effective policy and accountability outcomes (Obadan, 2009). This necessitated the paradigm shift from the traditional role of public administration, which focused largely on the bureaucratic features of top-down management system, established standards, hierarchy, inputs and procedures, to a New Public Management (NPM) model, which stress on productivity, marketization, service orientation, decentralization, and accountability (Levy, 2010; Heyer, 2011). This is not simply a matter of reform or a minor change in management style, but a change in the role of government in society and the relationship between government and citizenry, and an increase in demand for accountability (Bryson et al., 2014).

These waves of administrative reforms swept through the corridors of the public sector of most developing countries in the late 1980s. Most of these developing economies, especially sub-Saharan African countries embraced the neo-liberal economic policies of deregulation, liberalization, and privatization as a condition under the World Bank/IMF SAP (Bakre \& Lauwo, 2016). The weak financial position of SOEs (State Owned Enterprises) in many sub-Saharan African countries and their rapid deterioration, in conjunction with the fiscal crisis states experienced in the 1990s created some room for maneuver to implement privatization programs (Estrin \& Pelletier, 2018). Sharma (2011) opines that during this period, bureaucracies of most developing countries were not performing satisfactorily, so there was a need for them to be downsized through privatization and outsourcing (contracting-out) to the private sector. As one of such developing economies, Ghana went through the full rigorous process of public sector reforms under the Economic Recovery Programme (ERP) in 1987 (Afegbua \& Ejalonibu, 2015). "Ghana's initial reform program, the Civil Service Reform Program (1987-1994) was designed to reduce overstaffing and trim redundant civil servants as part of the effort to reduce government expenditure" (Owusu, 2006, p.3). This period of privatization was also characterized by management contracts with private firms which were met with public dissatisfaction (Danso, 1992).

This has to do with the opaque nature of Ghana's SOE privatization reforms and its adverse impact on accountability. Public agitations were attributed to accountability deficits such as corruption, nepotism, non-conformity to standards, political interference, and unclarity of government policies (Appiah-Kubi, 2001; Danso, 1992; Handley, 2007). The central tenets of accountability require a more transparent, open and responsive system (Jarvis, 2014; Lindberg, 2013). Accountability requires the government to provide policy oversight over the actions of contracted private firms and making the process more transparent and open for wider citizen engagement (Bovens, 2010; Brandsma \& Schillemans, 2013). However, accountability is compromised in the absence of strong institutional and legal framework in ensuring the compliance of the terms and conditions of divestiture, especially when there is a 
breach of contract (Adamolekun, 2010). This erodes the trust and confidence of citizens in the government and its institutions. As Cook (2018, p.319) aptly points out "where accountability mechanisms are faulty or non-existent, privatization can fail". Since the privatization of SOEs is mostly carried out by the government (partisan body), there is a tendency for partisan interference, which impedes the integrity of the bidding process (Handley, 2007). There is also the reluctance on the part of government in developing alternatives to the negotiated mode of divestiture that would foster and encourage broad public participation in the ownership of productive enterprise (Danso, 1992; Estrin \& Pelletier, 2018). Therefore, this paper seeks to examine the implication of the privatization of State-Owned Enterprises in Ghana on enhancing administrative and policy accountability of government.

The rest of the paper is organized as follows; the next section briefly outlines the methodology. The second section surveys the literature on the intellectual debate on the concept of accountability. In the third section, the essay touches briefly on an historical trajectory of SOE privatization experience in sub-Saharan Africa. The paper further lays the theoretical framework by examining the Principal-Agent theory within the broader framework of Accountability and Privatization. The fifth section explores the results of an empirical case study of Ghana Water Company Limited (GWCL). The paper therefore concludes with the implications of findings and policy lessons.

\section{Methodology}

\subsection{Research Design}

The study employed a qualitative research design. Qualitative research method is essential for studies that aim to undertake an elaborate or an in-depth study of a case or phenomena rather than just a provision of information in breadth from a large number of units (Creswell, 2003; Atkins \& Wallace, 2012). By adopting a qualitative approach, the study will be able to identify and assess the presence of core principles and virtues of accountability (transparency, openness, responsiveness, performance indicators) in the divestiture process. In terms of research strategy, this paper further adopts a case study approach which has been defined as "the intensive analysis (qualitative or quantitative) of a single unit or smaller number of units (the cases) where the researcher's goal is to understand a larger class of selected units (a population of cases)" (Gerring 2007, p. 20). Case study demands a detailed analysis of the case or subject being studied (Bryman and Bell, 2011). Case studies require a detailed consideration of contextual factors which is extremely difficult to find in statistical studies (George and Bennett, 2005). To avoid the issue of selection bias associated with case study, this essay provides a detailed justification for case selection.

\subsection{Justification for Case Selection-Representative Case}

The selection of the empirical case study follows the logic of representative (typical) case selection technique.Therefore, the careful selection of Ghana Water Company Limited (GWCL) as a case study is a typical representation of sub-Saharan Africa's adoption of SOE privatization policies which has been a long standing principle of the Worldbank/IMF 
(Bayliss, 2003). Specifically, it is representative of the privatization of state-owned enterprises in developing economies, especially, sub-Saharan African countries. As Gerring \& Cojocaru (2016) aptly points out, a typical case is intended to represent a broader population of cases in some relevant respect, which may be descriptive or causal. Gerring (2008, p.7) argues that "the typical case of some phenomenon may be helpful in exploring causal mechanisms and in solving identification problems". The GWCL case is representative (typical) of the wave of SOE reforms and accountability issues experienced in Ghana, and most sub-Saharan African countries. In this instance, the GWCL privatization phenomenon will be useful in assessing the problems (accountability deficits) posed by privatization, and the resilience and adaptability of the existing operational, technical and management capacity of SOEs in sub-Saharan Africa, and by providing tangible policy measures as a possible solution to these issues.

\subsection{Method of Data Collection and Limitations}

The study generally depends on both primary and secondary sources of data. Primary data includes; government documents, maintained websites, policy reports, and newspaper publications. Secondary data includes; academic and grey literature. In the process of collecting data and information, one major challenge and limitation this study encountered has been the availability of data. This study draws on available pieces of information and data sourced from scattered and a relatively small number of materials and references. The available data on the privatization of GWCL appears quite scanty and not neatly available. To present a systematic or coherent data, the researcher uniquely organizes these scattered pieces of data into time frames and events. However, challenging this may be, it is an opportunity to produce an original study with the expectation that future research would build on its findings.

\section{Literature Review}

\subsection{The Intellectual Debates on Accountability}

Accountability has been widely recognized as a fundamental value for good governance in public organizations (Al-Shbail \& Aman, 2018). Accountability is one of the primary aspects of public organizations that ensures the proper functioning and monitoring of main stakeholders (Ray, 2012). Even though the concept of accountability is well-known in the public administration literature, the concept has failed to reach an unequivocal meaning (Schillemans, 2010; Rached, 2016). Dubnick and Yang (2011, p.179) argue that "the promiscuity, multifunctionality, polymorphism, and situatedness of accountability make it one of the most elusive concepts in public administration". The absence of a clear conceptual definition of accountability has further exposed the concept to various interpretations and definitions by scholars (Schillemans, 2010). Bovens (2010, p.946) observes that even though "accountability has been used as a synonym for many loosely defined political desiderata, such as good governance, transparency, equity, democracy, efficiency, responsiveness, responsibility, and integrity, it has been a strong impediment for systematic comparative scholarly analysis". As a result of this disjointedness, accountability becomes an ever-expanding concept, which has come to stand as a general term for any mechanism that 
makes powerful institutions responsive to their particular publics (Bovens, 2010).

Brandsma \& Schillemans (2013, p.954) observes that "most scholars use the term mainly as a stepping stone for a normative assessment of a policy area". Hence, Bovens (2010) observes that accountability has been widely used as a normative concept, mainly as a set of well-established principles for regulating the actions and inactions of public officials or agents. These agents are to be held accountable for their acts of commission and omission (Grizzle \& Sloan, 2016). Bovens (2010) argues that accountability in this broad sense is adopted to positively qualify a state of affairs or the performance of an actor. It relates to responsiveness, responsibility, transparency, fairness, and equitability (Hall, 2011). However, there is no universally accepted standard or procedures for determining accountable behavior because these standards differ depending on role, institutional context, era, and political perspective (Greiling \& Spraul, 2010).

Moreover, in a narrower sense, accountability is seen as a social 'mechanism', as an institutional relation or arrangement in which an agent can be held to account by another agent or institution (Bovens, 2010). Bovens (2010, p.948) argues that "the locus of accountability studies is not the behaviour of public agents, but the way in which these institutional arrangements operate". This implies a communicative relationship between an accounter (person or organization) and an accountee (Bovens, 2010). Accountability as a social mechanism is usually enforced through procedures or institutional arrangements, while others are rules and regulations, such as sanctions (Adamolekun, 2010, Bovens, 2010; Hall, 2011; Barendrecht, 2011). However, Aguilar \& Saphores (2010) argues that accountability may become dysfunctional if too much emphasis on control leads to proceduralism (a rigid adherence to established procedures). Exhibiting blame avoidance behaviors and the desire to shield oneself from the threat of accountability, constitutes excessive proceduralism, which inhibits creative thinking, or sheer appearance of conformity with the expectations of the forum. Accountability overload is seen to reduce performance and erode public trust in democratic government (Olsen, 2015). This is the dilemma of accountability.

\subsection{Privatization of SOEs in Sub-saharan Africa}

Restructuring of state-owned enterprises in sub-Saharan Africa has been at the apex of the adjustment agenda since the 1980s (Obadan, 2009). This is because various attempts at reform had resulted in budget deficits and accrued financial loss (Appiah-Kubi, 2001). However, intergovernmental organizations emerged during the 1970s and 1980s embracing the meteoric rise of neoliberal principles of privatization (Obadan, 2009). Privatization was introduced in sub-Saharan Africa as a condition under the Structural Adjustment Program (SAP) of the two Bretton Woods institutions, the International Monetary Fund (IMF) and the World Bank (Boafo-Arthur, 1999; Appiah-Kubi, 2001; Sulemana, 2017).

There were political and economic conditions which necessitated the adoption of privatization policies in sub-Saharan Africa. Kayizzi-Mugerwa (2002) explains these conditions from two perspectives; the positivist and normative. With the wave of democratization spreading across sub-Saharan Africa in the 1990s, political liberalization created the avenue for governments to shift the focus from public to private oriented interest 
(Appiah-Kubi, 2001; Obadan, 2009). Kayizzi-Mugerwa (2002) provides insight into the positivist view by arguing that in sub-Saharan Africa, privatization is a politically charged subject. The positivist approach postulates that "privatization goes ahead only when politicians see clear-cut economic and political benefits" (Yeboah-Assiamah, 2015, p.227). Privatization served as a persuasive tool for mobilizing political support since it was regarded as a means for rent allocation (Tweneboah, 1999). The normative view postulates that privatization is necessary to develop the activities of the private sector, especially in addressing the issue of budgetary constraints (Yeboah-Assiamah, 2015; Kayizzi-Mugerwa, 2002). Privatization in sub-Saharan Africa was intended to minimize distortions associated with resource allocations, reduce social and economic inequalities, reduce budget deficits, reverse brain drain, create new employment opportunities, improve the efficiency of physical infrastructure, and improve the balance of payments. The primary objective was to promote the private sector as the main engine for economic growth (Tweneboah, 1999). The gap in the literature is that there are no theoretical explanations for the policy and accountability implication of the privatization of SOE in sub-Saharan Africa, specifically, Ghana. The novelty of this study is that, it essentially investigates the concept and principles of accountability through the lens of Principal-Agent theory, by focusing on the terms and conditions of divestiture.

\section{Theoretical Description}

\subsection{Principal-Agent Theory Within the Broader Framework of Accountability and Privatization}

The Principal-Agent theory has been a long-standing framework within the public administration literature (Aguilar-Benitez \& Jean-Daniel, 2010). Analysis and evaluation of accountability require a specification of who is (or is supposed to be) accountable to whom (Gailmard, 2012). In public administration literature, accountability is often modeled in a dyadic principal-agent model (Brandsma \& Schillemans, 2012). A group of actors called agents (subordinates) undertakes actions on behalf of the principal (superior) (Gailmard, 2012). According to Gailmard (2012), this is the core ingredient of principal-agent theory. In the principal-agent approach, the relationship between the accountor and the accountee is usually interpreted as one between the principal and agent (Krahmann, 2016).

Moreover, Zullo (2018, p.118) argues that "public-private contracts entail complications which are beyond the typical principal-agent relations due to the entangled public". Zullo (2018, p.118) further explains that three parties are often enshrined by a public-private contract: "the governmental agency, private contractor, and community". Zullo (2018) views privatization as a form of contract between two or more parties and provides a mechanism for enforcing compliance. He further argues that the split responsibility impairs monitoring. This usually happens when events occur in the community at the blind side of the government, and affected citizens are usually technically handicapped (ill-equipped to flag misspecifications, noncompliance, and moral hazards) in the monitoring of private contractor (Zullo, 2018). As Zullo (2018, p.118) aptly points out, "in many instances, citizens are unaware of the delegation of authority to a private producer, and even the informed are mostly ignorant of 
the contract terms that define contractor rights and responsibilities".

With Principal-Agent approach, what principals demand from the agent is transparency, inclusiveness, responsiveness, and a sense of ownership, which are the core principles of accountability. Accountability deficits emerge when mechanisms for holding public institutions or officials to account become less efficient or non-existent in the divestiture process. These deficits include; corruption, nepotism, confiscation of state resources, poor service delivery, and others. For principals to achieve accountability, there is a need for the incorporation of core principles of accountability in the divestiture process. Principal-Agent theory becomes problematic when system responsibility is at issue (Olsen, 2015). This has to do with monitoring, and operational issues (Olsen, 2015). The approach is even less useful when the task is to assess the impact of government policies, and instances where there are usually ideological conflicts over the actual and desired role of politics and government (Olsen, 2015). Additionally, Olsen (2015) argues that the approach fit democratic rhetoric better than democratic practices. Gailmard (2012) also argues that the approach inherits the weaknesses of game theory as a mechanism for explaining behavior.

Despite the shortcomings of the Principal-Agent approach, it provides structural mechanisms and incentives that principals can adopt in monitoring and controlling the activities of agents. The approach suggests that among others: (1) principals should establish entrenched rules, norms, and standards for their agents' behaviour; (2) there should be clarity and precision in the institutional or contractual relations between principals and agents; and (3) principals should provide agents with incentives to implement these standards and sanction non-compliance (Krahmann, 2016, p.1413).

\section{The Management Contract Between GWCL and AVRL (2006-2011)}

As part of the privatization agenda of the IMF/World Bank, and in an effort to improve urban water service delivery, in June 2006, a management contract was signed between Ghana Water Company Limited (GWCL), a state-owned enterprise and Aqua Vitens Rand Limited (AVRL) (a joint venture company between Vitens Evides International, The Netherlands and Rand Water Services, South Africa) a private consortium to manage urban water delivery across the country for a five (5) year period from June 2006 to June 2011 (Bohman, 2010; Ainuson, 2009). This was after AVRL emerged as the preferred bidding company, among other competing bidding companies, which were Saur and Veolia. The management contract was to transfer knowledge, skills, and resources from private companies and thus enhance the performance of GWCL (Mvulirwenande et al., 2015; Barendrecht \& Nisse, 2011; Yeboah, 2006).

"The management contract was signed within the framework of the Ghana Urban Water Project, which aimed to address these problems" (Mvulirwenande et al., 2019, p.18). This project composed of three basic components: "system expansion and rehabilitation; capacity development and project management; and a severance programme" (Mvulirwenande et al. 2019, p.18). The project was financed by the World Bank (US\$ 103 million, which was later turned into grant), the Nordic Development Fund (US\$ 5 million) and the Government of Ghana (US\$ 12 million) (Adu-Ampong, 2014; Whitfield, 2006; Bohman, 2010). "The World 
Bank was to provide US\$100 million to pay off redundant staff or workers who would be dismissed" (Mvulirwenande et al., 2019, p.18). As an agent of the principal (citizens), the government (GWCL) was "responsible for investment and monitoring the operator (the AVRL)" (Dagdeviren \& Robertson, 2013, p. 8). The broader objective of government was to; provide reliable supply and delivery of safe water in the urban sector; ensure low-income consumers had access to potable water at affordable prices; ensure sustainability of the sector through cost recovery; ensure an adequate and steady flow of investment funds, with an emphasis on low cost and concession financing; and support the introduction of the private sector into the management and operation of the sector under a management contract (Shang-Quartey, 2013).

As stipulated in the contract, the operator, AVRL was solely responsible for the operations of water supply, which includes; abstraction of raw water, treatment, and delivery of piped potable water; maintaining and improving customer records, billing, and collection; identifying and regularizing illegal connections; managing new water connections; training and managing GWCL staff seconded to AVRL; and reporting monthly to GWCL (Agyeman, 2007; Dagdeviren \& Robertson, 2013; Shang-Quartey, 2013). For instance, AVRL oversaw 85 treatment plants providing water to 55 separate service areas (Agyemang, 2007). AVRL was also given six (6) key performance indicators to achieve by the end of the contract. These included: (i) reduction in non-revenue water (NRW) by a minimum of 5\% per year (ii) increase in collection rates (iii) reduction in chemical and power consumption in production (iv) improved customer response (v) reduction in water consumption by the public sector entities (vi) maintaining water quality according to the established standards (GWCL, 2005 as cited in Dagdeviren \& Robertson, 2013, p.8).

AVRL was required under the contract to transfer any excess after covering operational costs to GWCL, which oversaw the investment. GWCL controlled the administrative structure and management of the company (Ainuson, 2010). AVRL was required to manage water supply more efficiently but was not mandated to bring in any capital. Investments were the sole responsibility of the Ghana Water Company (Ainuson, 2010). "2800 of the GWCL staff were seconded to the new operator, Aqua Vitens Rand Ltd, which is to act on behalf of GWCL until the contract period ends in 2011" (Bohman, 2010, p.109).

As part of the initiative, AVRL was guaranteed monthly fee by the World Bank grant in the form of an incentive-based contract during the privatization period (Bohman, 2010). Apart from this, there were payments due to the operator (AVRL) that were to be paid by the Ghana Water Company Limited (GWCL) (Shang-Quartey, 2013). Remuneration, as stated under the contract for the operator, entailed payment of a base fee which was to be adjusted occasionally based on the application of penalties and rewards schemes (Shang-Quartey, 2013). "The contract provided that base fee payment to the operator shall not be less than $85 \%$ of the fee, however, there was nothing in the contract that also allowed GWCL to base remuneration on performance." (Shang-Quartey, 2013, p.36). During the period of the management contract, the operator (AVRL) was mandated by the Grantor (GWCL) to have general control over the revenue collection account which was irrevocable (Shang-Quartey, 2013). The operator's working capital was to be paid back to the operator when the contract 
was completed or terminated, regardless of whether there are adequate or insufficient funds in the revenue collection account (Shang-Quartey, 2013). GWCL was made liable to cover the cost incurred.

In terms of liability, the contract provided "limited risks for the successful bidder and operator, and exposed GWCL to possible liabilities" that were to result from the implementation of the contract, as stated under section 6.4.2 of the contract (Shang-Quartey, 2013, p.37). Section 6.4.3 further provides a more explicit explanation to this provision; "The Grantor shall fully indemnify the Operator against all lawful costs, claims, demands and liabilities made by any third party to the Operator...unless such credits or the debts, liabilities and obligations are caused by the gross negligence of the Operator." (GWCL/AVARL 2005, p.17). Further, the liability of the operator (AVRL) was stipulated in the contract "not to exceed 20\% of the accrued base fee" (GWCL/AVARL 2005). This means that regardless of the amount of liability (cost) that the operator (AVRL) incurs, this insulation in the contract will further push liabilities in excess of the $20 \%$ base fee on the state (GWCL) (Shang-Quartey, 2013, p.37). The grantor (GWCL) was also obliged to facilitate relationships between the operator and state agencies for ease in the acquisition of authorizations that will be required from time to time in their work including for purposes of tax exemptions (Shang-Quartey, 2013, p.35). In terms of monitoring, it was stated in the contract that the GWCL shall supervise the AVRL in the discharge of its obligations (Shang-Quartey, 2013). GWCL shall critically assess and approve or offer a suggestion on all reports. It was also stated that "the Grantor shall be given reasonable access during normal working hours to premises, works and sites of the Operator for the purposes of inspection and certification" (GWCL/AVARL, 2005 as cited in Shang-Quartey, 2013, p.35-36).

\subsection{Implication for Policy and Accountability}

The GWCL privatization offers several policy implications for assessing the level of accountability in the divestiture process. Firstly, with regards to transparency, the opaque nature of the contract between GWCL \& AVRL appears to be one of the main deficiencies of the privatization policy. Transparency here, "refers to the availability of relevant information in adequate portions and in easily accessible forms to concerned stakeholders so that they can make informed decisions" (Zaato, 2014, p.692). Even the World Bank projects, the annual evaluation, and the Transaction Advisors reports were shrouded in secrecy by the agent (the government) (Zaato, 2014). Mvulirwenande et al. (2019) argue that there were ineffective dialogue and communication between the principal (citizens) and the agent (government), especially during the contractual agreement. This contract was decided by a group of technocrats, with limited consultations or participation in the decision-making process (Mvulirwenande et al. 2019; Zaato, 2011). Mvulirwenande et al. (2019) observe that the contract was initiated at the blind side of the principal, which led to subsequent public resistance. The massive public agitations and demonstrations against the management contract between AVRL and GWCL can be attributed to the lack of democratic accountability and monopoly that characterized the water sector reform process in Ghana (Fuest \& Haffner, 2007; Ainuson, 2010; Zaato, 2011). Most civil society organizations vigorously opposed the management contract (notably through public protests) and were very unwilling to cooperate 
with AVRL (Mvulirwenande et al. 2019; Fuest \& Haffner, 2007). For instance, the National Coalition Against Privatization (NCAP), the Integrated Social Development Centre (ISODEC), and the Trade Union Congress (TUC) decried what it saw as lack of transparency in the decision-making concerning water privatization (Whitfield, 2006). Also, there was labour unrest among GWCL workers who anticipated lay-offs and protested about the enhanced employment conditions of expatriate staff of AVRL compared to theirs (Hirvi, 2012). This led to intense pressure mounted on the government to abrogate the contract.

Secondly, the issue of asymmetric perspectives and information arose between GWCL and AVRL. In part, these problems were the effects of the misunderstanding between GWCL and the World Bank. Mvulirwenande et al. (2019) observes that GWCL remained unresponsive to the grievances of the private operator which emanates from the contract implementation. The terms and conditions of the contract vaguely described the relationship between GWCL and AVRL. The contract described AVRL as an independent contractor, not as an agent or partner of GWCL (Dagdeviren, 2013). GWCL was assigned a supervisory role, and the two parties are required to operate interdependently in the discharge of the management and operational duties. This accounted for the complications between the two parties especially when there is a need to take prudent management decisions (Dagdeviren, 2013; Mvulirenwenande et al., 2019). AVRL was also criticized for lacking adequate skills and a clear and purposeful strategy to communicate about the purported change across the utility sector.

Thirdly, the aggravated tensions between AVRL and GWCL under the management contract granted full control of revenue collection account to the private operator. As stipulated in the management contract, only the surplus after payment of all operating expenses was supposed to be paid to GWCL. However, on several occasions, GWCL top managers expressed their concerns about prudent account management practices and the revenue deficits. As Dagdeviren and Robertson (2013, p.12) aptly points out, “GWCL's lack of control over the revenue collection account coupled with fuzzy terms in the contractual spending hierarchy (such as 'reasonable and prudent maintenance costs') meant that the operator had very little incentive for surplus accumulation and transfer to the grantor". According to Zaato (2011), this arrangement represented a major accountability loophole. It appeared that the operator (AVRL) had more power over its remuneration than the Grantor (GWCL). AVRL employees were paid from two main sources: "the base fee negotiated during the bidding process, paid monthly from the World Bank funds; and a performance incentive paid from the revenue account (which was controlled by the operator)" (Mvulirwenande et al., 2019, p.22). This obviously limits the policy oversight responsibility of GWCL over the financial resources of AVRL.

Lastly, Mvulirwenande et al. (2019) argue that GWCL had no financial mechanisms to hold AVRL responsible, answerable and accountable for the targeted performance. These discrepancies may have accounted for the failure of AVRL in meeting its performance targets of reduction of non-revenue water by 5\% per year (Mvulirwenande et al. 2019). Non-Revenue Water is the losses incurred or accrued deficits in water production and delivery. In the case of GWCL, non-revenue water (NRW) remained very high under the management contract. A major result expected from the operator was the reduction of 
non-revenue water by $5 \%$ annually to about $25 \%$ by the end of the management contract (GWCL, 2018, p.19). However, by the close of the contract in 2011, NRW was still at an average of $50 \%$ (GWCL, 2018, p.19). The operator, AVRL also failed to meet key performance indicators such as bill collection, whilst water quality continued to deteriorate (Hirvi, 2012).

\section{Discussions of Findings}

\subsection{Implications of Findings for Literatures on Accountability Within the Framework of} Principal-Agent Theory

The findings of this study contribute to the intellectual debates on breaking down the barriers separating vertical and horizontal channels of accountability (Rached, 2016; Akpanuko \& Asogwa, 2013). Even though vertical accountability provides citizens (principal) with informal channels such as organizing themselves into associations capable of lobbying governments, demanding explanations, and threatening fewer formal sanctions, it lacks appropriate checks and balances, and other constitutional and legal tools in holding agents (state and its institutions) accountable. Such legal sanctions are eminent in horizontal accountability. With the water management contract, the findings of the study revealed that the bidding process was shrouded in secrecy, and that public agitations were not enough to halt the implementation of the contract. The study holds the implication that merging vertical and horizontal accountability will ensure the incorporation of monitoring and evaluation measures and strict conformity to key performance indicators. This ensures that citizens (principal) hold agents (government) accountable through both informal and formal channels such as the court. There should be a fair and robust legal framework and policy incentives which must guide the divestiture process.

This also has implications for the long-standing issue with the principal-agent approach, which is the asymmetric information problem. This is where the agent is seen as an expert and is allowed to withhold vital information from the public (principal). Resorting to legal procedures will be pivotal in dealing with this issue. Overall, the study supports the assertion that accountability should be enforced through institutional arrangements (established rules and procedures) (Adamolekun, 2010, Bovens, 2010; Hall, 2011; Barendrecht, 2011).

\subsection{Implications for Monitoring and Evaluation as a Core Principle of Accountability}

Monitoring and Evaluation as a key component of the contractual agreement between parties provide the framework for tracking the performance of the other party. It provides a template for ensuring that the terms and conditions of the contract have been fulfilled by the other party. For instance, during policy agreements, the government (agent) on his part must ensure the incorporation of monitoring and evaluation measures in tracking the performance of the concessionaire. The absence of monitoring and evaluation measures also makes it more complex for the government (agent) to exercise its policy oversight role over the concessionaire. Penalties or sanctions must be applied to the terms of a policy agreement and must be enshrined and dictated by rules and regulations, devoid of manipulations and abuse by the authority. By so doing, sanctions will be duly enforced to either party whenever there 
is a breach of contract, and most importantly, the principals' interest will be sustained. There is also a need for policy autonomy whereby the rules of divestiture are made to dictate the policy direction. Dagdeviren and Robertson (2013) argue that the absence of baselines and its attendant challenges could be avoided if public authorities endured the strict adherence of the monitoring and evaluation measures. The contract could have specified the penalties and incentives rather than leaving them for the operator to determine (Dagdeviren, \& Robertson, 2013; Shang-Quartey, 2013). For instance, the penalty for non-compliance with the NRW reduction target was left to the operator to propose. Dagdeviren and Robertson (2013, p.14) note that "the ambiguities in the terms and conditions could have been reduced had legal experts and advisers been more closely engaged within the process of contract development". "As of 2010, one year before the expiry of the contract, the agreements between the grantor and the operator were still pending on the details of indicators, baselines, penalties, and incentives" (Dagdeviren \& Robertson, 2013, p.10).

\subsection{Policy Lessons}

Firstly, the need to incorporate mechanisms such as accessibility to information in any policy agreement is paramount to ensuring accountability. The legal framework should establish, with a maximum degree of public disclosure, the terms of divestiture. If the primary focus of a government policy is geared towards citizens' welfare, then there is the need to uphold these accountability mechanisms in policy formulation and implementation. For instance, information regarding the criteria for assessing the technical and operational capacity of the concessionaire must be made publicly accessible. The Right to Information (RTI) bill recently passed by the government with approval from Parliament, is a step in the right direction in ensuring public access to information from public offices on request or without request and participation in the governing process. The Act is meant to put in effect, Article 21 (1) (f) of the 1992 Constitution of the Republic of Ghana which states that "All persons shall have the right to information subject to such qualifications and laws as are necessary for a democratic society" (CLD, 2018, p.2). The main purpose of the Act "as set out in its preamble is to provide for the implementation of the constitutional right to information held by any public institution and to foster a culture of transparency and accountability in public affairs" (Shaban, 2019, p.1).

Lastly, Krahmann (2016) provides useful insights into the structural mechanisms and incentives that principals can adopt in controlling the activities of agents. He delineates three basic measures which include; (1) principals should establish rules, norms and standards for their agents' behavior, which implies conformity to the terms and conditions of the contract ; (2) there should be clarity and precision in the institutional or contractual relations between principals and agents; and (3) principals should provide agents with incentives to implement these standards and sanction non-compliance (Krahmann, 2016, p.1413). However, this does not only suggest the adoption of a mechanistic approach to accountability, where there is strict adherence to rules, but also a social form of accountability that ensures openness, transparency, and effective participation (consensus building) in policy formulation and implementation. To achieve broader citizen engagement, the government of Ghana must ensure the inclusion and strict enforcement of local content policy in contractual terms with 
prospective bidding companies.

\subsection{Practical Implications to an Ongoing Privatization Phenomenon}

In light of the empirical analysis of the privatization of GWCL, some policy lessons can be distilled and applied to the ongoing Electricity Company of Ghana (ECG) privatization. Having been approved by cabinet and ratified by parliament, the Government of Ghana signed a 20-year concession agreement with a private consortium, Power Distribution Services (PDS) Ghana Limited leading to the eventual take-off on February 27, 2019 (GhanaWeb, 2019). This was in fulfillment of the Power Compact signed between the Government of Ghana, and the United States of America, acting through the Millennium Challenge Corporation (MCC) (GhanaWeb, 2019). It was known as the Ghana Compact of the Millennium Challenge Compact II (MCC, 2014). A key objective of the compact II is to promote private sector participation whilst upholding good governance, economic freedom and investment (MCC, 2014). The Power Distribution Services (PDS) Ghana Limited is composed of Manila Group (holding 30 percent), AEnergia SA of Angola (holding 19 percent), and a 51 percent stake held by three local private investors (TG Energy Solutions Ghana Limited, Santa Power Limited, and GTS Power Limited) (GhanaWeb, 2019).

However, there are accountability deficiencies evident in the privatization process. There were some lapses in providing justification for the selection of a preferred bidder. There were not enough details provided on the terms and conditions of the bidding process which is contained in the Request for Proposal document. In a press statement, Public Utilities Workers Union (PUWU) questioned the competitiveness of the bidding process since there were only two bidding companies to select from and this leaves the government with limited options (GhanaWeb, 2018). Again, the bidding process and criterion for selecting the Ghanaian private firms (TG Energy Solutions Ghana Limited, Santa Power Limited, and GTS Power Limited) were not publicly disclosed. This has thrown Ghanaians into a policy dilemma as they continue to question the financial and operational capacity of these three indigenous private firms. For instance, an issue worthy of concern is the authenticity of the demand guarantee submitted by the concessionaire. The credibility of the financial guarantors of PDS also remains unknown to the public. This brings to light a major deficiency of the Principal-Agent model, which has to do with the problem of adverse selection, where the government (agent) withhold vital information from the citizens (principal). This is also informed by information asymmetries, whereby citizens (principal) consider the government or policymakers (agent) to be experts in making informed policy decisions (Olsen, 2015).

First, to enhance accountability, government must ensure that sanctions are clearly spelled out in the Government Support Agreement (GhanaWeb, 2019). Even though it is stated under the Government Support Agreement that the government is required to provide a sovereign guarantee to indemnify the Concessionaire for any substantial breach by ECG for the terms and conditions under the Lease and Assignment Agreement and Bulk Supply Agreement, it is still unclear the sanctions or penalties in place, in the event of a breach of contract by the concessionaire.

Secondly, government must ensure the execution of the Monitoring Schedule and Protocol 
Agreement which is key to safeguarding, monitoring, and insuring the assets of ECG during the concession period (GhanaWeb, 2019). There should be parameters in place to ensure ECG monitor the activities of the concessionaire. Failure to do so, ECG will not be able to ensure that its assets are effectively managed by PDS (the operator). For instance, the failure to incorporate monitoring and evaluation measures made it virtually impossible for AVRL, the operator to achieve its targets. Also, the successful privatization of electricity in India and Uganda was due to the strict compliance of monitoring and evaluation measures set out to the concessionaire (USAID, 2014).

Lastly, the government must ensure the full public disclosure of the content of the policy document. The information contained in the document must be readily available and accessible to the public. For instance, there should be timely reports and media publications of PDS operations. The terms of the contract must be clearly explained to Ghanaians (principal). It is obvious that the failure on the part of the government (agent) to do so, has resulted in diverse interpretations by sections of the media, and other stakeholders. The silence of government (agent) has further created fear and panic among Ghanaians, who anticipate the collapse of their businesses, local content issues, and other unforeseen consequences.

\section{Conclusion}

Ghana's privatization experience has not been all rosy due to administrative and policy accountability deficiencies which engulfed the divestiture process. This is also evident in public agitations and dissatisfaction during the contract period. These factors provided enough justification for the Government of Ghana not to extend AVRL's contract beyond its expiration in June 2011. The empirical evidence presented in this study demonstrates that the success of privatization policies is largely contingent on the effective utilization of core principles of accountability. Not only are these elements critical in themselves, together, they represent the most important structural, political and administrative contingency factors to consider if policymakers are to be successful in the reform process. They constitute the core tenets and undergirding principles for the creation of citizen-centred, and accountable public organizations that fit the needs of different politico-administrative systems.

\section{Acknowledgement}

My profound gratitude goes to my mentor and supervisor, Professor Charles Conteh of the Department of Political Science, Brock University, for his assiduous guidance and inputs throughout this project. He has been a great pillar in the pursuance of my academic career. I wish to also dedicate this excellent piece to Ms. Jocelyn Agyare for her immeasurable support throughout this research. To my wonderful and supportive family, I say God richly bless you.

\section{References}

Adamolekun, L. (2010). The governors and the governed: Towards improved accountability for achieving good development performance. Africa Review, 2(2), 105-138. https://doi.org/10.1080/09744053.2010.10597295 
Afegbua, S. I., \& Ejalonibu, G. L. (2015). Emerging Issues in Public Sector Reforms in Africa: An Assessment of Ghana and Nigeria. Africa's Public Service Delivery \& Performance Review, 95-126. https://doi.org/10.4102/apsdpr.v3i3.91

Aguilar-Benitez, I., \& Jean-Daniel, S. (2010). Public accountability and performance of two border water utilities. Water Policy, 12(2), 203-219. https://doi.org/10.2166/wp.2009.032

Ainuson, K. G. (2010). Urban Water Politics and Water Security in Disadvantaged Urban Communities in Ghana. African Studies Quarterly, 11(4), 59-82.

Akpanuko, E. E., \& Asogwa, I. E. (2013). Accountability: A Synthesis. International Journal of Finance and Accounting, 2(3), 164-173.

Al-Shbail, T., \& Aman, A. (2018). E-government and accountability. Transforming Government: People, Process and Policy, 12(2), 155-190. https://doi.org/10.1108/TG-09-2017-0057

Appiah-Kubi, K. (2001). State-Owned Enterprises and Privatization in Ghana. The Journal of Modern African Studies, 39(2), 197-229. https://doi.org/10.1017/S0022278X01003597

Atkins, L., \& Wallace, S. (2012). Research Methods in Education: Qualitative research in education. London: SAGE Publications Ltd. https://doi.org/10.4135/9781473957602

Bakre, O. M., \& Lauwo, S. (2016). Privatisation and accountability in a "crony capitalist" Nigerian state. Critical Perspectives on Accounting, 39, 45-58. https://doi.org/10.1016/j.cpa.2016.01.003

Barendrecht, A., \& Nisse, M. (2011). Management Contract 2006-2011 for Urban Water Supply in Ghana. A Partnership - in and for - Development. Vitens-Evides International, The Netherlands.

Barendrecht, M. (2011). Rule of law, measuring and accountability: Problems to be solved bottom up. Hague Journal on the Rule of Law, 3(2), 281-304. https://doi.org/10.1017/S1876404511200071

Bayliss, K. (2003). Utility Privatisation in Sub-Saharan Africa: A Case Study of Water. The Journal of Modern African Studies, 41(4), 507-531. https://doi.org/10.1017/S0022278X03004415

Boafo-Arthur, K. (1999). Ghana: Structural adjustment, democratization, and the politics of continuity. African Studies Review, 42(2), 41-72. https://doi.org/10.2307/525364

Bohman, A. (2010). Framing the Water and Sanitation Challenge: A History of Urban Water Supply and Sanitation in Ghana.1909-2005. Sweden-Umeò.

Bovens, M. (2010). Two concepts of accountability: Accountability as a virtue and as a $\begin{array}{lllll}\text { mechanism. West } & \text { European }\end{array}$ https://doi.org/10.1080/01402382.2010.486119

Brandsma, G. J., \& Schillemans, T. (2013). The Accountability Cube: Measuring 
Accountability. Journal of Public Administration Research and Theory, 23(4), 953-975. https://doi.org/10.1093/jopart/mus034

Bryman, A., \& Bell, E. (2011). Business research methods. Cambridge ; New York, NY : Oxford University Press.

Bryson, J. M., Crosby, B. C., \& Bloomberg, L. (2014). Public Value Governance: Moving Beyond Traditional Public Administration and the New Public Management. Public Administration Review, 74(4), 445-456. https://doi.org/10.1111/puar.12238

Centre for Law and Democracy (CLD) (2018). Ghana: Analysis of the Right to Information Bill.https://www.law-democracy.org/live/wp content/uploads/2018/06/Ghana.FOI_.Jun18.pdf

Cook, B. J. (2018). Old and new: Privatization and the accountability challenge. Administration \& Society, 50(3), 319-320. https://doi.org/10.1177/0095399717754097

Creswell, J. W. (2003). Research Design: Qualitative, Quantitative and Mixed Methods Approaches (2nd ed.). Thousand Oaks: Sage.

Dagdeviren, H., \& Robertson, S. A. (2013). A critical assessment of the incomplete contracts theory for private participation in public services: the case of the water sector in Ghana. Cambridge Journal of Economics. https://doi.org/10.1093/cje/bet007

Danso, A. (1992). Privatization of State-Owned Enterprises in Africa: The Case of Ghana. South Eastern Political Review, 335-351. https://doi.org/10.1111/j.1747-1346.1992.tb00314.x

Dubnick, M. J., \& Yang, K. (2011). The Pursuit of Accountability: Promise, Problems, and Prospects, in D. C. Menzel and H. White (eds.), The state of public administration: issues, challenges, and opportunities (pp. 171-186). Armonk, NY: M.E. Sharpe, forthcoming.

Estrin, S., \& Pelletier, A. (2018). Privatization in Developing Countries: What Are the Lessons of Recent Experience? The World Bank Research Observer, 33(1), 65-102. https://doi.org/10.1093/wbro/lkx007

Fichtner, H. W. (2010). 4th Year Management Contract - Technical Audit Report. Accra: GWCL/World Bank.

Fuest, V., \& Haffner, S. A. (2007). PPP - policies, practices and problems in Ghana's urban water supply, Water Policy, 9, 169-192. https://doi.org/10.2166/wp.2007.060

Gailmard, S. (2012). Accountability and principal-agent models. Berkeley, CA: Berkeley University.

George, A. L., \& Bennett, A. (2005). Case studies and theory development in the social sciences (4th ed.). Cambridge, MA: MIT Press.

Gerring, J. (2007). Case study research: Principles and practices. Cambridge University Press. https://doi.org/10.1017/CBO9780511803123

Gerring, J., \& Cojocaru, L. (2016). Selecting Cases for Intensive Analysis: A Diversity of Goals and Methods. Sociological Methods \& Research, 45(3), 392-423. 
https://doi.org/10.1177/0049124116631692

GhanaWeb. (2018). ECG takeover: PUWU questions MiDA's selection of Meralco. [Online] Available:

https://www.ghanaweb.com/GhanaHomePage/NewsArchive/ECG-takeover-PUWU-question s-MiDA-s-selection-of-Meralco-644904 (April 20, 2018).

GhanaWeb. (2019). New company takes over ECG on February 1.[Online] Available: https://www.ghanaweb.com/GhanaHomePage/business/New-company-takes-over-ECG-on-F ebruary-1-714317 (January 11, 2019).

GhanaWeb. (2019). PDS takes over ECG today after initial postponement. [Online] Available: https://www.ghanaweb.com/GhanaHomePage/business/PDS-takes-over-ECG-today-after-init ial-postponement-726643 (February 27, 2019).

GhanaWeb. (2019). Privatisation of ECG operations starts. [Online] Available: https://www.ghanaweb.com/GhanaHomePage/business/Privatisation-of-ECG-operations-start s-720262 (February 2, 2019).

Greiling, D., \& Spraul, K. (2010). Accountability and the Challenges of Information Disclosure. Public Administration Quarterly, 34(3), 338-377.

Grizzle, C., \& Sloan, M. F. (2016). Assessing Changing Accountability Structures Created by Emerging Equity Markets in the Nonprofit Sector. Public Administration Quarterly, 40(2), 387-408.

GWCL/AVARL. (2005). Management Contract for Ghana Urban Water. Accra: GWCL and AVRL.

Hall, A. T., \& Ferris, G. R. (2011). Accountability and extra-role behavior. Employee Responsibilities and Rights Journal, 23(2), 131-144. https://doi.org/10.1007/s10672-010-9148-9

Handley, A. (2007). Business, Government, and the Privatisation of the Ashanti Goldfields Company in Ghana. Canadian Journal of African Studies, 41(1). Canadian Business \& Current Affairs Database. https://doi.org/10.1080/00083968.2007.10751350

Heyer, G. (2011). New public management. Policing, 34(3), 419-433. https://doi.org/10.1108/13639511111157492

Hirvi, M. (2012). Water Privatization and Social Citizenship: The Case of Urban Water Sector in Ghana, Journal of Civil Society, 8(4), 351-368. https://doi.org/10.1080/17448689.2012.744231

Jarvis, M. D. (2014). The black box of bureaucracy: Interrogating accountability in the public service. Australian Journal of Public Administration, 73(4), 450-66. https://doi.org/10.1111/1467-8500.12109

Kalimullah, N. A., Alam, K. M. A., \& Nour, M. M. A. (2012). New Public Management: Emergence and Principles. BUP Journal, 1(1), 1-22. 
Kayizzi-Mugerwa, S. (2002). Privatization in sub-Saharan Africa on Factors Affecting Implementation. Helsinki: UNU World Institute for Development Economics Research (UNU/WIDER) Discussion Paper No. 2002/12.

Krahman, E. (2016). NATO contracting in Afghanistan: the problem of principal-agent networks, International Affairs, 92(6), 1401-1426. https://doi.org/10.1111/1468-2346.12753

Levy, R. (2010). New public management: End of an era? Public Policy and Administration, 25(2), 234-240. https://doi.org/10.1177/0952076709357152

Lindberg, S. I. (2013). Mapping accountability: core concept and subtypes. International $\begin{array}{llll}\text { Review of } & \text { Administrative } & \text { 202-226. }\end{array}$ https://doi.org/10.1177/0020852313477761

MCC (2014). Millennium Challenge Compact Between the United States of America Acting Through the Millennium Challenge Corporation and the Republic of Ghana. https://www.mida.gov.gh/pages/view/43/MCA_CompactII-0.pdf

Mvulirwenande, S., Wehn, U., \& Alaerts, G. (2019). Policy factors explaining the failure of delegated management in water supply: evidence from Ghana, Water International, 44(1), 14-30. https://doi.org/10.1080/02508060.2018.1539697

Obadan, M. I. (2009). Economic and Social Impact of Privatisation of State-owned Enterprises in Africa. Oxford: African Books Collective. Retrieved from: Project MUSE database.

Olsen, J. P. (2015). Democratic order, autonomy, and accountability. Governance, 28(4), 425-440. https://doi.org/10.1111/gove.12158

Owusu, F. (2006). Differences in the Performance of Public Organizations in Ghana: Implications for Public Sector Reform Policy. Development Policy Review, 24(6), 693- 705. https://doi.org/10.1111/j.1467-7679.2006.00354.x

Rached, D. H. (2016). The concept(s) of accountability: Form in search of substance. Leiden Journal of International Law, 29(2), 317-342. https://doi.org/10.1017/S0922156516000042

Ray, S. (2012). Reinforcing accountability in public services: An ICT enabled framework. Transforming Government: People, Process and Policy, 6(2), 135-148. https://doi.org/10.1108/17506161211246890

Robinson, M. (2015). From old public administration to the new public service: implications for public sector reform in developing countries. Singapore: United Nations Development Programme, Global Centre for Public Service Excellence.

Schillemans, T. (2010). Redundant Accountability: The Joint Impact of Horizontal and Vertical Accountability on Autonomous Agencies. Public Administration Quarterly, 34(3), 300-337.

Shaban, A., \& Rahman, A. (2019). Ghana president assents to Right to Information bill. [Online] Available: 
https://www.africanews.com/2019/05/22/ghana-president-assents-to-right-to-information-bill/ / (May 22, 2019).

Shang-Quartey, L. (2013). From Private Sector Participation to Full Public Ownership: Why the Urban Water Management Contract in Ghana was discontinued. Retrieved from: LShang_moodledata_temp_turnitintool_212682749._94_1384335988_2167\%20(2).pdf

Sharma, V., \& Yadav, A. K. (2011). A Study of Disinvestment and Privatization Polices of PSU In India. Journal of Commerce \& Trade, 6(1), 112-116.

Sulemana, S. (2017). A Multiple Streams Approach to Understanding Social Policy in Ghana: The Case of Livelihood Empowerment Against Poverty. Journal of Public Administration and Governance, 7(4), 198-210. https://doi.org/10.5296/jpag.v7i4.11903

Tweneboah, F. D. (1999). Privatisation of a Large State Corporation - Some Issues Arising. Paper Presented at a Workshop on Privatisation and Infrastructure Development, Accra: GIMPA.

USAID. (2014). Ghanaians Discuss Privatization Options with India and Uganda. https://www.usea.org/sites/default/files/Ghana\%20article.pdf

Whitfield, L. (2006) The politics of urban water reform in Ghana. Review of African Political Economy, 33(109), 425-448. https://doi.org/10.1080/03056240601000812

Yeboah, I. (2006). Subaltern strategies and development practice: urban water privatization in Ghana. The Geographical Journal, 50-65. https://doi.org/10.1111/j.1475-4959.2006.00184.x

Zaato, J. J. (2014). Look before you leap: lessons from urban water sector reforms in Ghana. Journal of Asian African Studies 0021909614541077. https://doi.org/10.1177/0021909614541077

Zullo, R. (2018). Explaining Privatization Failure: The Vice of Sweet Carrots and Hard Sticks. Review of Radical Political Economics, 51(1), 111-128. https://doi.org/10.1177/0486613417718527

\section{Copyright Disclaimer}

Copyright for this article is retained by the author(s), with first publication rights granted to the journal.

This is an open-access article distributed under the terms and conditions of the Creative Commons Attribution license (http://creativecommons.org/licenses/by/4.0/). 